\title{
THE FAM LIFESTYLE ON THE EXAMPLE OF SOCCER FANS
}

\author{
Tomasz Brzana, ${ }^{1, A, B, C, D}$ Leonard Nowak, ${ }^{1, A, D, E}$ Maria Alicja Nowak ${ }^{2, A, C, D}$ \\ ${ }^{1}$ Faculty of Physical Culture in Gorzow Wielkopolski, University School of Physical Education in Poznan, Poland \\ 2 Faculty of Physical Culture and Health Promotion, University of Szczecin, Poland

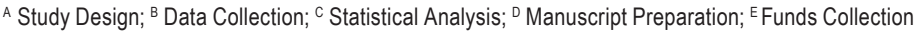 \\ Address for correspondence: \\ Maria Alicja Nowak \\ University of Szczecin, Faculty of Physical Culture and Health Promotion \\ Al. Piastów 40b, building 6, 71-065 Szczecin, Poland \\ E-mail: maria-nowak@wp.pl
}

\begin{abstract}
Ahstract The aim of this study was to investigate chosen aspects of the lifestyle of soccer fans. Methods. The study was conducted among 200 fans. In the study a diagnostic survey was employed, with the use of the techniques of questionnaire, interview, document analysis and participant observation. In order to draw statistical conclusions, the trait frequency, the independence $x^{2}$ test and multiple correspondence analysis were used. Results. The community of active fans is characterized by various kinds of behavior. Fans aged $15-19$, for whom important motives for cheering were the opportunity to be with a group and a sense of connectedness, as well as a sense of strength and power, declared consumption of alcoholic beverages before matches. For fans aged 20-24, who more often practiced combat sports and exercised in the gym, an important motive for cheering was the opportunity to meet their friends and let off steam during the match. They regarded devastation of sports facilities and burning scarves as acts of hooliganism. Fans aged 25-29, and 30 or above admitted that they sometimes consumed alcoholic beverages before the game. Conclusions. There is a necessity to educate children and youth in sports cheering.
\end{abstract}

Key WOrds active fan, family's support, combat sports, motives for cheering, hooliganism

\section{Introduction}

Sports cheering is generally a positive phenomenon. Some believe true supporters are people who come to the venue only to see the sports event, for others true supporters are those fans who cheer their team. Among fans, just like in any small community, there are diverse behaviors (positive and negative). Soccer fans are most often talked about when negative behaviors take place in or beyond stadiums. The negative image of a soccer fan which dominates the reports is stereotypically transferred to the entire collectivity.

Despite fans also engaging in socially desirable activities, these groups are associated with stadium hooligans. There are few publications describing the positive activity of soccer fans, especially the ultras groups and their lifestyle (Karaś, 2010; Pilz, 2009; Sahaj, 2007; Wąsowicz, 2012, 2015).

Far more publications concern stadium hooliganism (Piotrowski, 2000; Kowalski, 2000; Dudała, 2004; Chlebowicz, 2009; Pływaczewski, Wiśniewski (ed.) 2012). Problems emerging in stadiums lead to tensions between 
hooligans and the police and the media (Piotrowski, 2012). Causes of disorderly behavior are analyzed in the context of preventive measures (Pałaszewski, 2011; Wądołowska, 2012).

Another perspective in which to view the phenomenon of hooliganism is given by Milcarz (2006), who compares the behavior and values of the members of the fighting squads (organized hooligan groups) to the chivalric ethos. A story has been written about everyday life of the supporters of the "Stilon" Gorzów Wielkopolski Sports Club (Korsak, 2012). Rooting for a team is also popular with school youth (Babik, 2010). An indispensable source of knowledge is the periodical "We the fans", which has been issued in Poland by fans every month for more than 15 years. It contains essays written by the supporters themselves which provide insight into the circles of soccer fans.

The structure of the fans' community is subject to evolution (Kowalski, 2000; Piotrowski, 2012). In this paper, an original division of fans into two groups was used: active supporters (stadium hooligans, ultras, scarfers, elders) and passive supporters (picnics, seasoners, sympathizers, global supporters, connoisseurs of soccer). Ultras could be defined as a supporters' movement aimed at the loudest possible rooting for a team and presenting displays in the stands, consisting of flags, cardboard, balloons and pyrotechnics. One of the common features of the European ultras is deriving pleasure and satisfaction from creative cheering during the match, as well as from pre-match preparations. In contrast to many other supporter activities, you are not an ultra only on the weekend, but for the whole week. Everything is subordinated to soccer and/or to the fan movement (Karaś, 2010).

Although ultras are not hooligans, in the event of spontaneous brawls they also take part in the fight. They do not, however, participate in other forms of hooligan activity. Ultras are considered second category supporters by hooligans, but the members of ultras groups "are content with such "medium" fan mentality, with a penchant for risk and adventure on the one hand, and fascination with the atmosphere of stadium stands on the other" (Jaworski, 2004, p. 15). This work concentrated on the characteristics of active fans (hooligans, ultras and scarfers), as those who are the most recognizable and characteristic of the fan community.

In many interviews with fans of various teams the concept of fan lifestyle appears. This concept is present in songs recorded by soccer fans and can also be found on T-shirts, sweatshirts or fan stickers. Starting from the concept of lifestyle (Siciński, 2002), one can refer it to the community of soccer fans. Fan groups are characterized by a specific system of values, motives, norms and behaviors. They stand out from society. Individuals representing the fan lifestyle attend matches in their location, participate in away games, and take other actions associated with the fan movement (e.g. the creation of graffiti), subordinating their professional and personal plans to the soccer league match schedule.

The aim of the study was to investigate chosen aspects of the lifestyles of soccer fans supporting the "Stilon" Gorzów Wielkopolski Sports Club.

The following hypotheses were formulated:

1. Most soccer fans practice combat sports.

2. Active cheering is supported by most soccer fans' families.

3. Motives for cheering change with respondents' age.

4. Sports fans exhibit positive and negative behaviors. 


\section{Research material and methods}

Research within the community of soccer fans has been conducted since 2013. A study of 200 fans of the "Stilon" Gorzów Wielkopolski Sports Club, with material gathered during matches in Gorzów Wielkopolski, as well as during away matches, is the basis for the present work. The majority of active fans were males (90\%) residents of Gorzów Wielkopolski (79\%). The subject were people of different ages (15-50 years old), school and higher education students (46.5\%), working (47\%). The supporters of the "Stilon" Gorzów Wielkopolski Sports Club create a unique group. Despite the Club announcing its bankruptcy twice in the past several years (which each time resulted in starting the next season in the lowest division), the fans have still stayed with the Club. In 2011, after the second announcement of bankruptcy, the Club's fans became members of the new management to create the team from scratch. The access to the relatively closed environment of fans, who agreed to the study being conducted and consented to participant observation, was possible because one of the authors of this work is an active fan of the "Stilon" Gorzów Wielkopolski Sports Club.

In the study a diagnostic survey was employed, with the use of the following techniques: questionnaire, interview, document analysis and participant observation. Purposeful sampling was used which included only active fans. Uncategorized interviews were conducted with the leaders of the hooligan group and the ultras group. The interviews were not recorded, however, because these people, in order to maintain full anonymity, did not give their consent to it. The study was supplemented with participant observation. The techniques used made it possible to gather detailed information on the phenomena occurring during away matches (especially on trips to the matches), as well as at meetings of members of various fan groups. The contents found on the fan forum and in fan papers were also analyzed.

The qualitative and quantitative analysis was carried out with the employment of standard statistical methods: frequency of characteristics, chi-squared independence test and multiple correspondence analysis (van Bureen, de Leuve, 1992). These analyses are available in the statistical software package Statistica 12 (StatSoft, inc. 2015 Statistica for Windows).

\section{Research results}

Social characteristics of the supporters of the "Stilon" Gorzów Wielkopolski Sports Club.

Most supporters attended their first match at a young age (Figure 1).

The subjects most often started their cheering adventure between the ages of 12 and 16 . The youngest fan was 7 and the oldest one was 18 years old. The fan community is diverse in terms of age, but it mainly consists of young people (Table 1). The subjects were people aged 15-50. Respondents under 24 years of age accounted for $66.5 \%$ of all the subjects, that is $2 / 3$ of the fans. The fan community is formed primarily by men ( $90 \%)$. Female supporters were aged 15-19. After 30 years of age women cease to be active fans. Almost half of the respondents had already started working (47\%). A similar number of them continued education. Among the supporters some people were also unemployed (6.5\%).

A statistically significant correlation was found between the active rooting and the place of residence and education (in each case: $p \leq 0.05$ ). The active supporters are mainly residents of Gorzów Wielkopolski, but the 15-19 age group was dominated by residents of neighboring towns and villages. The subjects were characterized 
by secondary education. In the 20-24 age group there was the largest number of people with post-secondary education.

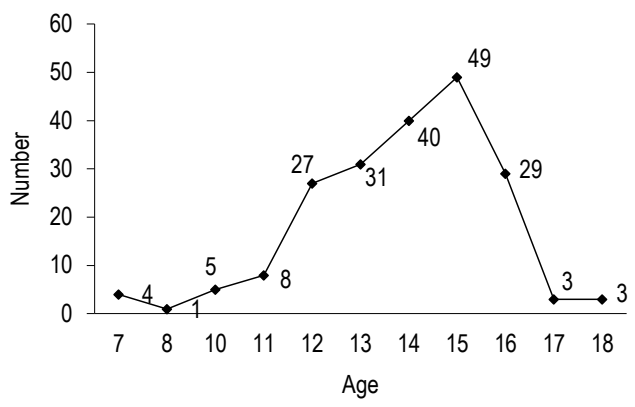

Figure 1. Fan initiation age (n)

Table 1. Social characteristics of the supporters of the "Stilon" Gorzów Wielkopolski Sports Club in relation to age (independence $x^{2}$ test)

\begin{tabular}{|c|c|c|c|c|c|c|}
\hline \multirow[b]{2}{*}{ Specification } & \multicolumn{4}{|c|}{ Age (in years) } & \multirow{2}{*}{\multicolumn{2}{|c|}{ Total $(n=200)$}} \\
\hline & $15-19$ & $20-24$ & $25-29$ & $\geq 30$ & & \\
\hline \multicolumn{7}{|l|}{ Sex: } \\
\hline - Male & 66.7 & 96.5 & 95.0 & 100.0 & 180 & 90.0 \\
\hline - Female & 33.3 & 3.5 & 5.0 & - & 20 & 10.0 \\
\hline \multicolumn{7}{|l|}{ Professional work: } \\
\hline - school student & 95.8 & 1.2 & - & - & 47 & 23.5 \\
\hline - higher education student & 2.1 & 52.9 & - & - & 46 & 23.0 \\
\hline - working & - & 32.9 & 100.0 & 97.9 & 94 & 47.0 \\
\hline - unemployed & 2.1 & 12.9 & - & 2.1 & 13 & 6.5 \\
\hline \multicolumn{7}{|l|}{ Place of residence*: } \\
\hline - Gorzów Wlkp. & 60.4 & 80.0 & 85.0 & 93.6 & 158 & 79.0 \\
\hline - Vicinity & 39.6 & 20.0 & 15.0 & 6.4 & 42 & 21.0 \\
\hline \multicolumn{7}{|l|}{ Education*: } \\
\hline - pre-secondary & 31.2 & 15.3 & 10.0 & 6.4 & 33 & 16.5 \\
\hline - secondary & 66.7 & 34.1 & 80.0 & 78.7 & 114 & 57.0 \\
\hline - post-secondary & 2.1 & 50.6 & 10.0 & 14.9 & 53 & 26.5 \\
\hline
\end{tabular}

${ }^{*}$ Statistical significance for $p \leq 0.05$.

The largest proportion of the supporters was interested in sport (92.5\%) (Table 2). This interest was predominant in all the age categories. The high ranking of sport was strengthened by the subjects' declarations concerning on the one hand practicing extreme sports (22.5\%), and on the other health promoting activities (fitness and dance) $(14 \%)$. Dancing was preferred by the female fans. More than half of the subjects were passionate about music (51\%). Many fans were interested in film and the arts $(40.5 \%)$ as well as history and architecture (29.5\%). The automotive industry $(37.5 \%)$ and computers (29\%) were also passions of about $1 / 3$ of the respondents. Among the subjects 
aged 15-19 the greatest interest in music was observed (73\%) as compared to the other age categories. This correlation was statistically significant $(p \leq 0.05)$. The interest in history and architecture distinguished individuals aged $20-24$ from the rest $(41.2 \%)(p \leq 0.05)$. The group of 25-29-year-olds was more often interested in motor vehicles $(50 \%)$ and computers $(45 \%)$.

Table 2. The supporters' interests in relation to age (independence $x^{2}$ test)

\begin{tabular}{|c|c|c|c|c|c|c|c|c|c|c|}
\hline \multirow{3}{*}{ Interests } & \multicolumn{10}{|c|}{ Subjects' age } \\
\hline & \multicolumn{2}{|c|}{$15-19$} & \multicolumn{2}{|c|}{$20-24$} & \multicolumn{2}{|c|}{$25-29$} & \multicolumn{2}{|c|}{30 and older } & \multicolumn{2}{|c|}{ Total } \\
\hline & $n$ & $\%$ & $n$ & $\%$ & $n$ & $\%$ & $\mathrm{n}$ & $\%$ & $\mathrm{n}$ & $\%$ \\
\hline Sport & 43 & 89.6 & 79 & 92.9 & 18 & 95.7 & 45 & 95.7 & 185 & 92.5 \\
\hline Music $^{*}$ & 35 & 73.0 & 42 & 49.4 & 5 & 25.0 & 20 & 42.6 & 102 & 51.0 \\
\hline Film, arts & 14 & 29.2 & 37 & 43.5 & 11 & 55.0 & 19 & 40.4 & 81 & 40.5 \\
\hline Motor vehicles & 15 & 31.3 & 32 & 37.7 & 10 & 50.0 & 18 & 38.3 & 75 & 37.5 \\
\hline History, architecture* & 9 & 18.8 & 35 & 41.2 & 3 & 15.0 & 12 & 25.5 & 59 & 29.5 \\
\hline Computers & 13 & 27.1 & 22 & 25.9 & 9 & 45.0 & 14 & 29.8 & 58 & 29.0 \\
\hline Extreme sports & 11 & 22.9 & 19 & 22.4 & 3 & 15.0 & 12 & 25.5 & 45 & 22.5 \\
\hline Collectables & 5 & 10.4 & 22 & 25.9 & 6 & 30.0 & 11 & 23.4 & 44 & 22.0 \\
\hline Books & 4 & 8.3 & 13 & 15.3 & 3 & 15.0 & 10 & 21.3 & 30 & 15.0 \\
\hline Tourism & 6 & 12.5 & 15 & 17.7 & 1 & 5.0 & 8 & 17.0 & 30 & 15.0 \\
\hline Dance, fitness & 12 & 25.1 & 10 & 11.8 & 3 & 15.0 & 3 & 6.4 & 28 & 14.0 \\
\hline Politics & 4 & 8.3 & 16 & 18.8 & 0 & - & 7 & 14.9 & 27 & 13.5 \\
\hline Other & 9 & 18.8 & 11 & 13.0 & 2 & 10.0 & 2 & 4.2 & 24 & 13.5 \\
\hline
\end{tabular}

* Statistical significance for $p \leq 0.05$.

Combat sports and strength training were the most popular among the supporters (Table 3). Almost half of them practiced combat sports. The most frequently chosen disciplines were boxing, kick-boxing and Brazilian jujitsu. Several people also trained Mixed Martial Arts (MMA) or karate. Persons between 15 and 24 years of age accounted for almost $70 \%$ of those practicing combat sports. A high percentage of those who exercised in the gym $(64 \%)$ indicates that fans attached great importance to the development of their strength and led an active lifestyle.

Table 3. Physical activity of soccer fans (\%)

\begin{tabular}{lcccccccccc}
\hline & \multicolumn{10}{c}{ Subjects' age } \\
\cline { 2 - 11 } \multicolumn{1}{c}{ Specification } & \multicolumn{1}{c}{$15-19(48)$} & \multicolumn{2}{c}{$20-24(85)$} & \multicolumn{2}{c}{$25-29(20)$} & 30 and older (47) & \multicolumn{1}{c}{ Total (200) } \\
\cline { 2 - 11 } & $\mathrm{n}$ & $\%$ & $\mathrm{n}$ & $\%$ & $\mathrm{n}$ & $\%$ & $\mathrm{n}$ & $\%$ & $\mathrm{n}$ & $\%$ \\
\hline Combat sports & 24 & 50.0 & 47 & 40.0 & 6 & 30.0 & 21 & 44.4 & 95 & 47.5 \\
Exercise in gym & 26 & 54.2 & 57 & 67.1 & 16 & 80.0 & 29 & 61.7 & 128 & 64.0 \\
\hline
\end{tabular}

*Combat sports: boxing, kick-boxing, Brazilian ju-jitsu, karate, MMA (Mixed Martial Arts).

Almost $1 / 3$ of the fans had another active supporter in their family (31\%). Most frequently the other fans in the family were: brother $(48 \%)$, cousin $(30 \%)$, father $(7.5 \%)$, son $(6 \%)$ and uncle $(4 \%)$. Occasionally they were also mother, husband or sister ( $5 \%$ each). A relatively high percentage of respondents who had another soccer fan in 
the family, indicates that this passion is transmitted by people in the immediate surroundings. Due to the subjects' financial dependence, with the expenses associated with rooting (the cost of tickets, fares), help is necessary, mostly from the family. A correlation was found between the family's acceptance and family members' active cheering ( $p \leq 0.05$ ) (Figure 2). Most active fans are supported by their families (87.1\%). About $13 \%$ of the respondents had to face the lack of acceptance of active cheering.

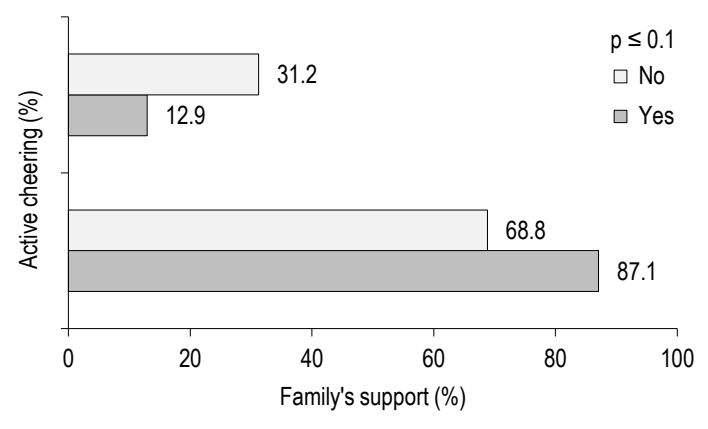

( $p \leq 0.05$ for the independence $X^{2}$ test)

Figure 2. Family's support in relations to the family members' participation in cheering

In addition to the support from family members, active cheering requires time planning. $57.5 \%$ of the respondents always adjusted their personal and professional plans to the dates of local and away matches, and $33.5 \%$ did it frequently. Among active fans, those who did not plan their participation in soccer matches in advance constituted $9 \%$. The majority of fans aged $15-19$ and $20-24$ subordinated their time to the match schedule $(70 \%$ and $58 \%$ resp.). In the older age categories personal and professional plans were less often adjusted to the dates of matches.

Most of the subjects wanted to help their team to victory with their active rooting (Table 4). It is important for an individual to consolidate friendship and make new acquaintances within their own group. Maintaining ties with supporters of other teams and being together in a group are of sociocentric character. Some groups of fans are linked together (e.g. through unions i.e. friendships between fans of different clubs). For the majority of respondents being a fan was an opportunity to root for the team and let off steam. This can be done within one's own group or be a demonstration of dominance over other fans, a display of strength and power before other fan groups.

There was a statistically significant relationship between the subjects' age and their motives for being a fan. Meeting friends was an important motive for supporters aged 20 and above $(p \leq 0.05)$. The same age groups were also motivated by the opportunity to let off steam ( $p \leq 0.05$ ). The motives for being a fan for people aged $15-19$ were the sense of connectedness ( $p \leq 0.05)$, the opportunity to be together in a group ( $p \leq 0.05)$, and the sense of strength and power $(p \leq 0.05)$. 
Table 4. Motives for being a fan (independence $x^{2}$ test)

\begin{tabular}{|c|c|c|c|c|c|c|c|c|c|c|}
\hline \multirow{3}{*}{ Specification } & \multicolumn{10}{|c|}{ Age (in years) } \\
\hline & \multicolumn{2}{|c|}{$15-19$} & \multicolumn{2}{|c|}{$20-24$} & \multicolumn{2}{|c|}{$25-29$} & \multicolumn{2}{|c|}{30 and older } & \multicolumn{2}{|c|}{ Total } \\
\hline & $\mathrm{N}$ & $\%$ & $\mathrm{~N}$ & $\%$ & $n$ & $\%$ & $\mathrm{n}$ & $\%$ & $n$ & $\%$ \\
\hline Helping the team & 45 & 93.8 & 61 & 71.8 & 19 & 95.0 & 40 & 85.1 & 165 & 82.5 \\
\hline Meeting friends ${ }^{*}$ & 27 & 56.3 & 69 & 81.2 & 17 & 85.0 & 39 & 83.0 & 152 & 76.0 \\
\hline Satisfaction & 33 & 68.8 & 68 & 80.0 & 13 & 65.0 & 31 & 65.7 & 145 & 72.5 \\
\hline Cheering atmosphere & 31 & 64.6 & 55 & 64.7 & 9 & 45.0 & 29 & 61.7 & 124 & 62.0 \\
\hline Opportunity to let off steam* & 16 & 33.3 & 56 & 65.9 & 16 & 80.0 & 33 & 70.2 & 121 & 60.5 \\
\hline Sense of connectedness ${ }^{*}$ & 36 & 75.0 & 44 & 51.8 & 4 & 20.0 & 11 & 23.4 & 95 & 47.5 \\
\hline Domination over other fans & 24 & 50.0 & 41 & 48.2 & 8 & 40.0 & 15 & 31.9 & 88 & 44.0 \\
\hline New acquaintances & 24 & 50.0 & 27 & 31.8 & 9 & 45.0 & 5 & 10.6 & 65 & 32.5 \\
\hline Being together in a group* & 21 & 43.8 & 20 & 23.4 & 4 & 20.0 & 2 & 4.3 & 47 & 23.5 \\
\hline Entertainment & 10 & 20.8 & 12 & 14.1 & 3 & 15.0 & 4 & 8.5 & 29 & 14.5 \\
\hline Sense of strength and power* & 16 & 33.3 & 18 & 21.2 & 2 & 10.0 & 1 & 2.1 & 37 & 13.5 \\
\hline
\end{tabular}

* Statistical significance for $p \leq 0.05$.

Misunderstandings between soccer fans and the security forces are often caused by aggressive behavior of those fans who consume alcoholic beverages before matches.

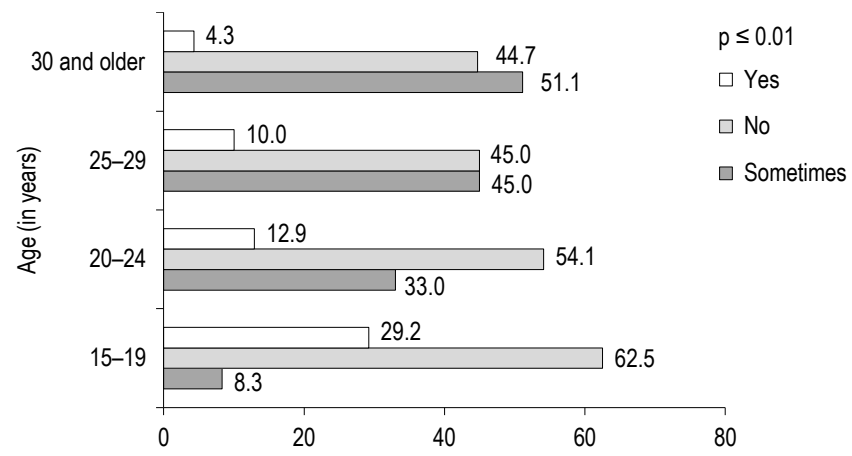

(\%)

Figure 3. Alcoholic beverages consumption before matches (independence $x^{2}$ test)

Alcoholic beverages were consumed before most matches by $15 \%$ and sometimes by $32.5 \%$ of the respondents. There was a statistically significant correlation between consumption of alcoholic beverages and the age of the subjects $(p \leq 0.01$ ) (Figure 3). Drinking alcohol before most matches was the most common phenomenon among the youngest people (15-19 years old) (29.2\%). Occasional consumption of alcoholic beverages was declared by fans aged 30 and above (51.1\%). 
The concept of being a hooligan in view of the fans examined most often had a positive dimension (only $2.5 \%$ of them associated it with negative behaviors). Hooligans were associated primarily with squads' duels (prearranged fights between hostile groups of hooligans, held in secluded places away from stadiums), toward which most of the supporters had a positive attitude. The subjects believed that squads' duels were a good way to show which team had better fans and which club dominated. This opinion was expressed by $83.4 \%$ of the fans. Only $3.5 \%$ of the subjects considered them to be wrong, and $13.1 \%$ of the respondents had no opinion.

In the view of the subjects, acts of hooliganism principally included three offenses: devastation of sports facilities, direct aggression (hitting, beating) used toward other fans, and attacking the police and security forces (Table 5). A statistically significant correlation was observed between the age of the fans and recognition of devastation of facilities and burning scarves as acts of hooliganism ( $p \leq 0.05$ in each case). The greatest liberalism toward these behaviors was characteristic of young supporters aged 15-19, with short histories of being fans. Firing of pyrotechnics, which are usually used by ultras groups for adding visual effects to their displays at matches, was not an act of hooliganism according to the greatest number of fans.

Table 5. Types of acts of hooliganism in the opinion of the subjects (independence $x^{2}$ test)

\begin{tabular}{|c|c|c|c|c|c|c|c|c|c|c|}
\hline \multirow{3}{*}{ Type of act } & \multicolumn{10}{|c|}{ Age (in years) } \\
\hline & \multicolumn{2}{|c|}{$15-19$} & \multicolumn{2}{|c|}{$20-24$} & \multicolumn{2}{|c|}{$25-29$} & \multicolumn{2}{|c|}{30 and older } & \multicolumn{2}{|c|}{ Total } \\
\hline & $\mathrm{N}$ & $\%$ & $n$ & $\%$ & $n$ & $\%$ & $n$ & $\%$ & $n$ & $\%$ \\
\hline Devastation of a facility* & 33 & 68.8 & 73 & 85.9 & 19 & 95.0 & 47 & 100.0 & 172 & 86.0 \\
\hline Direct aggression & 39 & 81.3 & 71 & 83.5 & 18 & 90.0 & 37 & 78.7 & 165 & 82.5 \\
\hline Attacking the police & 30 & 62.5 & 70 & 82.4 & 18 & 90.0 & 40 & 85.1 & 158 & 79.0 \\
\hline Burning scarves* & 9 & 18.8 & 35 & 41.2 & 5 & 25.0 & 15 & 31.9 & 64 & 32.0 \\
\hline Verbal aggression (toward fans, referee, players) & 9 & 18.8 & 15 & 17.6 & 4 & 20.0 & 12 & 25.5 & 30 & 20.0 \\
\hline Firing of pyrotechnics & 1 & 2.1 & 5 & 5.9 & - & - & 2 & 4.3 & 8 & 4.0 \\
\hline
\end{tabular}

* Statistical significance for $p \leq 0.05$.

In performing a graphical analysis of the results of the correspondence analysis in relation to two dimensions in space the four age categories were kept. The first one was comprised of supporters aged 15-19, for whom important motives for cheering were the opportunity to spend time in a group (5a), a sense of connectedness (6a), and a sense of strength and power (10a), and who attached less importance to the opportunity to let off steam (4b). They less frequently perceived devastation of sports facilities as an act of hooliganism (8b). The group of 15-19-year-olds declared consumption of alcoholic beverages before matches (7a).

Fans aged 20-24 practiced combat sports (1a), attended the gym (2a), and were motivated to cheer their team by the possibility of meeting up with friends ( $3 a$ ) and letting off steam during matches (4a). Being together with a group was of less importance (5b), as was the sense of strength and power (10b). They recognized as acts of hooliganism devastation of sports facilities (8a) and burning scarves (9a).

Fans aged 25-29 and 30 and above did not associate being a fan with a sense of connectedness (6b), and admitted (51.1\%) that they sometimes consumed alcoholic beverages before matches (7c).

Peripheral position was occupied by supporters who did not drink alcohol before matches (7b) as well as those for whom meeting friends while rooting for their team was less important (3b). In the vicinity of each of the groups were those who did not practice combat sports (1b) or work out in the gym (2b) and did not recognize burning scarves as an act of hooliganism (9b). 


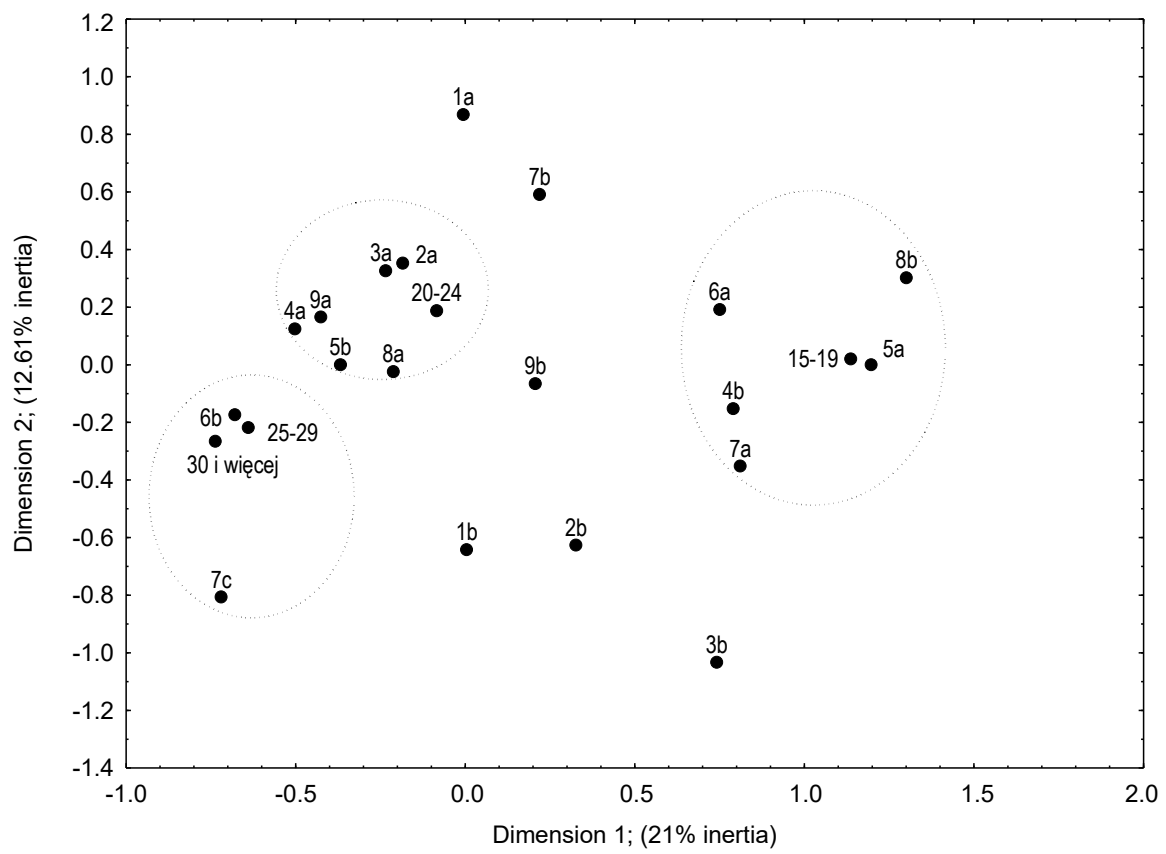

Figure 4. Correlations between the age, education, motives for cheering, practicing sports, alcoholic beverages consumption and recognition of acts of hooliganism by fans (MCA)

\section{Discussion}

The community of active soccer fans, namely those who participate actively in rooting for their team at home and go to away matches, is primarily comprised of young people. The results of the present study (interviews with hooligans) and research by D. Cholewa (as quoted in: Babik, 2010, p. 84) have confirmed that people usually join hooligan groups at the age of 16-19. The observations have shown that even young schoolchildren are now involved in cheering. They come to the stadium with their parents or other family members. As the fans say: "It is these children that will be like us in future".

Men constitute the vast majority of the community of fans. In the case of the supporters of the "Stilon" Gorzów Wielkopolski Sports Club, women-mainly young girls aged 15-19-accounted for $10 \%$. In another study, out of 318 fans of Zagłębie Sosnowiec only 9 were female (Dudała, 2004). Favorable changes in the community of supporters may result in an increase in the number of female fans. Stadiums, including "the mills" (the sectors where the most active fans of the home teams are located), have become more friendly, and the fan community less aggressive. Also, women's soccer teams have been established, which can affect the growth of interest in this sports discipline among girls. Over the years, the structure of supporters' education has changed. The percentage of fans who are higher education students has risen considerably. At the beginning of this century it amounted to about 3-4\% of the population of fans (Dudała, 2004). In the present research, $21.5 \%$ of the supporters were studying. As far as fans of the "Stilton" Sports Club are concerned, $46.5 \%$ of them were currently either learning at 
schools or studying at higher education institutions, and the proportion of those who were employed was almost the same (47\%); the unemployed accounted for $6.5 \%$. The percentage of unemployed fans was lower than half the national average unemployment rate, which amounted to 13.9\% (Central Statistical Office, February 2014).

The community of fans of the "Stilon" Sports Club is mainly comprised of residents of Gorzów Wielkopolski (79\%). The remaining supporters are inhabitants of villages and nearby towns. As for the whole country, these proportions are different. The best Polish teams, for example "Lech" Poznań, "Legia" Warsaw or "Widzew" Lódź, have so called fan clubs (FCs), i.e. organized groups of supporters coming also from other cities. They usually have their own flag with the emblem of the team they support and the name of the place which they come from. Still another situation can be observed concerning fans in the Upper Silesia: the proximity of the cities makes a lot of fans travel to matches of teams different than those which play in the place of their residence, e.g. "in Gliwice, fans of "Górnik" Zabrze operate vigorously (Kuczyński, 2011) (the so called Torcida Gliwice), and the inhabitants of Katowice root for "Ruch" Chorzów (the so called Blue Katowice).

Interest in sport was declared by over $90 \%$ of the supporters. They most often practiced combat sports. The skills acquired in combat sports training sessions are used by hooligans during squads' duels and other forms of fighting with supporters of opposing teams. It is sometimes the case that new members are recruited for the fighting squads from the combat sports clubs. "During the practices, effective combinations of blocks, grips and blows are tested. Hooligans learn to fight in a way which will allow them to rapidly defeat the opponent" (Sahaj, 2007 , p. 142) It has been found that people aged $15-24$ account for $70 \%$ of those practicing combat sports. This is probably connected with the nationwide trend concerning squads' duels, in which only people up to 21 years of age are to participate. Individuals who practice combat sports, however, should not be perceived as hooligans. The results of research carried out among athletes with a high sporting level indicate that their motives were different from those of hooligans and that they more often observed the principles of a healthy lifestyle. "Athletes with the highest sporting level (champions) mostly did not smoke (93.3\%) and abstained from drinking alcoholic beverages (59.1\%)" (Nowak, Umiastowska, Nowak, 2013, p. 41). The hypothesis concerning the preference of combat sports by sports fans was confirmed.

Most hooligans would not like their children to join a group like theirs (Babik, 2010). This demonstrates the hooligans' awareness of the consequences which being in a fighting squad entails. For supporters, especially the minors, it is important that their passion be accepted by their family (also for financial reasons). A large proportion of soccer fans participate in most of the matches of their team, both at home and away. Few fans attend their team's games occasionally. As is apparent from the interviews, this group may be comprised of hooligans, who avoid matches which are less interesting for them. They are present, however, at games at which fans of antagonistic teams are to appear.

Most of the active fans of the "Stilon" Gorzów Wielkpopolski Sports Club adjust their professional and family plans to the match schedule. "For those individuals, work and family take second place; the performance of their favorite team is the most important" (Dudała, 2004, p. 23). N. Hornby (2003, p. 196) wrote in his memoirs: "I'm ready to watch any game, anytime, anywhere, regardless of the weather". Approximately $50 \%$ of the subjects went to most or all away matches. These data cannot be referred to all the Polish fan groups in general, because the proportions in bigger clubs are considerably different from those in smaller ones.

This state of affairs is influenced, among other things, by the number of tickets allocated for matches in Ekstraklasa (the top division in Polish soccer) and the costs of travel. Participation in away games, especially by the 
younger supporters, would not be possible without the approval and financial support of the family. The hypothesis that most of the active fans receive support from their families was confirmed.

The fans of the "Stilon" Gorzów Wielkopolski Sports Club most often reported that they attended matches because they wanted to help the team with cheering. In the stands, lasting friendships are formed; there is an opportunity for socializing. Cheering is a source of personal satisfaction. In a national magazine about sports fans a fan wrote regarding rooting: "And what's so beautiful about it? Dedication, which each of us puts in to travel with our team. Love - not for money, not for honors. It's for the beautiful moments that can never be forgotten" (Przemek (Lechia Gdańsk), 2011, p. 41). This text perfectly illustrates the motives that attract soccer fans to the stands. The above words were also confirmed by this study, because in both cases the motives are related to helping the team, friendship, and personal satisfaction. At the same time, differences in motives for rooting can be observed with respect to particular age categories. A sense of strength and power over the group of fans of the opposing team and reign over the stadium were mostly motives for participation in cheering for people aged 15-19. These behaviors require targeted pedagogical measures. The hypothesis about the evolution of motives for rooting depending on age was confirmed.

There are both socially acceptable and deviant behaviors among soccer fans. In recent years, supporters of the "Stilon" Gorzów Wielkopolski Sports Club have run several charity campaigns, e.g. they have donated blood and volunteered as potential bone marrow donors. The "Blue and Whites" fan association has organized holiday soccer training for school children, which was conducted by players of the Gorzów Wielkopolski Soccer Club (contemporary name of the "Stilon" Gorzów Wielkopolski Sports Club). During the 2013/2014 season "Stilon" fans ran the "Blue and white Santa Claus" campaign, during which they visited the children's home and gave presents to about 50 wards of this institution. In March of 2014 supporters of the "Stilon" Gorzów Wielkopolski Sports Club organized a collection of food and other necessary articles for the Gorzów Wielkopolski dog shelter. In earlier years, funds for the sick were raised at the stadium. In addition to charity campaigns, the club's supporters help with the work done at the stadium, like renewal of ticket offices or clearing snow from the pitch. They also assisted in the reactivation of the club. Similar behaviors of Polish fans have been described by Prendecki (2012). Most of such activities are not heard of in the media, because the fans are reluctant to provide the television or newspapers with this kind of information (72.5\% of them do not trust the media). Following an activity the information appears on the team's website, summarizing the actions taken and encouraging further ones.

In view of the respondents, acts of hooliganism included: devastation of a facility, direct aggression used toward fans of other teams, attacking the police, and burning scarves. The report of the Polish Football Association (PZPN) lists several offenses which did not appear among the responses from fans of the "Stilon" Gorzów Wielkopolski Sports Club. Those are, among others: uncontrolled intrusion on the premises of a facility, throwing objects at members of security forces, putting up flags with illegal content (Report of the PZPN, 2005). According to the data of the Police Headquarters, the number of hooligan excesses decreased tenfold between 1997 and 2010 (Piotrowski 2012, p. 72). However, apart from acts of hooliganism at stadiums and squads' duels, a few others can still be distinguished. Kołek and Mikołajczyk (2010) mention the following: an attack on the visiting team's fans during their journey to the game (stopping the train with the emergency brake followed by an attack on the hostile fans) and devastating public transport. The leaders of supporters encourage and even require behavior which is consistent with the accepted social norms. Not everybody observes these requirements, which sometimes leads to damage to public property. 
Not infrequently, soccer fans commit acts prohibited by law in and beyond stadiums (Journal of Laws of 2009, No. 62, item 504; Journal of Laws of 2015 item 1707). In most cases, members of hooligan groups are responsible for deviant behavior. Such situations often require intervention by the police, who along with other public order services (e.g. security staff) are viewed negatively in the community of soccer fans (Babik, 2010). "The hatred toward public order services prevailing among hooligans and ultras stems from the unjustified, in their opinion, brutality with which they are treated by law enforcement officers" (Piotrowski, 2012, p. 51). Supporters also protest against the Law on Security of Mass Events (Journal of Laws of 2009 No. 62, item 504; Journal of Laws of 2015 item 1707), under which the courts can impose stadium bans on them. In the interviews, fans of the "Stilon" Gorzów Wielkopolski Sports Club stressed that they understood the sanctions imposed for brawls in stadiums, but were opposed to punishing people with stadium bans for e.g. taking a seat other than that which is assigned to the ticket, standing on the stairs between sectors or failure to obey the instructions of public order services. The last mentioned plea, concerning failure to comply with orders of security staff, was deemed unconstitutional by the Constitutional Court in May 2014 (Ref. file No. K 17/13).

Misunderstandings between fans and the security forces are often caused by aggressive behavior of the fans who consume alcoholic beverages before matches. In the case of fans of the "Stilon" Gorzów Wielkopolski Sports Club, alcoholic beverages are regularly drunk before the game by $15 \%$ of the respondents, the largest proportion of them being those aged 15-19 (29.2\%). The observations confirmed that "(...) the most valiant ones, the true fight pickers, they rather shun alcohol. They prefer to stay sober so they can fight" (Kowalski, 2000, p. 47).

There is a controversy about participation in squads' duels. It was not mentioned by fans of the "Stilon" Gorzów Wielkopolski Sports Club among acts of hooliganism. Squads' duels are considered a good form of rivalry and confrontation between hooligans. Held outside the stadiums, they do not threaten the safety of other people and do not expose the club to financial responsibility as the brawls that erupt in the stands do. It should be emphasized that nowadays hooligans themselves often provide order in the stands, i.e. they ensure that other fans do not commit offenses. T. Sahaj is of the view that "if hooligans take care of their affairs in this way, they should be left to their fate. If only this does not harm outsiders, let them even physically eliminate each other during such squads' duels" (Sahaj, 2007, p. 143), but there are consequences of such acquiescence: people breaking the law and then using public hospitals if injured (Sahaj, 2007).

In our opinion, there is also a risk of the violence used by the participants of squads' duels being transferred to everyday life. The hypothesis concerning diverse, positive and negative, behaviors of soccer fans of the "Stilon" Gorzów Wielkopolski Sports Club was confirmed.

Based on research conducted in the community of active supporters, having considered their specific standards of behavior, motives for cheering, preparation of displays for matches (a form of spectacle performed by the ultras), adjustment of their professional and personal plans to the match schedule, and a specific way of dressing, it can be stated that the fans have created a separate sports fan lifestyle, distinguishing them from other social groups (Siciński, 2002). The community of fans use specific linguistic expressions, which can be considered a sports fan jargon. Soccer fans are also distinguished by wearing clothes in the colors of their club, and an active fan's attribute is a club scarf. 


\section{Conclusions}

1. The community of fans of the "Stilon" Sports Club is mainly comprised of residents of Gorzów Wielkopolski who practice combat sports and exercise in the gym.

2. Active cheering is accepted and supported financially by most soccer fans' families.

3. The main motives for cheering were: helping the team, meeting up with friends, and satisfaction. For the youth aged 15-19 spending time with a group was important, as well as a sense of connectedness and a sense of strength and power. Supporters who were 20 years of age and older appreciated the opportunity to meet up with friends and let off steam during the match.

4. The community of active fans is characterized by various kinds of behavior (positive and negative). Accurate determination of these behaviors is difficult due to controversial provisions relating to cheering.

5. Alcohol consumption before matches concerns nearly half of the supporters surveyed.

6 . There is a necessity to educate children and youth in sports cheering.

\section{References}

Babik, M. (2010). Szkoła wobec subkultury pseudokibiców. Kraków: WAM.

Chlebowicz, P. (2009). Chuligaństwo stadionowe. Studium kryminologiczne. Warszawa: Wydawnictwo Wolters Kluwer.

Dudała, J. (2004). Fani-chuligani. Rzecz o polskich kibolach. Studium socjologiczne. Warszawa: Wydawnictwo Akademickie "Żak".

Hornby, N. (2003). Futbolowa gorączka. Translated by M. Hesko-Kołodzińska. Poznań: Wydawnictwo ZYSK i S-ka.

Jaworski, P. (2004). Czym jest ultra? To My Kibice, 4 (31), 15.

Karaś, M. (2010). Kibicowanie jako uniwersalny język. Żelechów: Wydawnictwo sendsport.pl.

Kołek, K., Mikołajczyk, P. (2010). Etiologia przestępczości stadionowej i chuligaństwa futbolowego oraz analiza wybranych koncepcji ich zwalczania. In: W. Pływaczewski, J. Kudrelek (eds.), Przestępczość stadionowa. Etiologia, fenomenologia, przeciwdziałanie zjawisku. Szczytno: Wydawnictwo Wyższej Szkoły Policji.

Korsak, K. (2012). Jestem kibolem. Brzezia Łąka: Poligraf.

Kowalski, R. (2000). Potomkowie chuligana. Szalikowcy. Toruń: Wydawnictwo Adam Marszałek.

Kuczyński, T. (2016). Miejsce zamieszkania nie określa kibicowania. Retrived from: phttp://ekstraklasa.net/miejsce-zamieszkania-nieokresla-kibicowania,artykul. html?material_id=4ed89a2916f1da6109000000 (16.05.2016).

Miesięczna informacja o bezrobociu rejestrowanym w Polsce w lutym 2014 r. Retrived from: http://stat.gov.pl/obszary-tematyczne/ rynek-pracy/bezrobocie-rejestrowane//miesieczna-informacja-o-bezrobociu-rejestrowanym-w-polsce-w-lutym-2014-r-,1, 24.html : Główny Urząd Statystyczny, 2014 (16.05.2015).

Milcarz, T. (2006). Rycerze w szalikach. Subkultura chuliganów piłkarskich w koncepcji Ericha Fromma. Szczecin: My Book.

Nowak, M., Umiastowska, D., Nowak, L. (2013). Selected behaviors and health awareness of athletes practicing martial arts. Journal of Combat Sports and Martial Arts, 1, 41-46.

Pałaszewski, P. (2011). Policyjne zabezpieczenie przejazdów kibiców piłki nożnej. In: T. Sahaj (ed.), Od fana do chuligana. Poznań: Monografia nr 410, AWF Poznań.

Pilz, G.A., Wolki-Schumacher, F. (2010). Przegląd zjawiska kultury Ultra w krajach członkowskich Rady Europy w 2009 r. Hannover.

Piotrowski, P. (2012). Chuligani a kultura futbolu w Polsce. Warszawa: Wydawnictwo Naukowe PWN.

Piotrowski, P. (2000). Szalikowcy. O zachowaniach dewiacyjnych kibiców sportowych. Toruń: Wydawnictwo Adam Marszałek.

Pływaczewski, W., Wiśniewski, B. (eds.). (2012). Przestępczość stadionowa. Diagnoza i przeciwdziałanie zjawisku. Szczytno: Wydawnictwo Wyższej Szkoły Policji.

Prendecki, K. (2012). Kibice i okolice. Warszawa: The Facto.

Raport o stanie bezpieczeństwa na stadionach piłkarskich. (2005). Warszawa: Wydawnictwo PZPN.

Sahaj, T. (2007). Fani futbolowi. Historyczno-społeczne studium zjawiska kibicowania. Poznań: Monografia nr 377, AWF Poznań.

Siciński, A. (2002). Styl życia. Kultura. Wybór. Warszawa. 
Ustawa z dnia 11 września 2015 r. o Bezpieczeństwie imprez masowych Dz.U. 2015 poz. 1707.

Ustawa z dnia 20 marca 2009 r. o Bezpieczeństwie imprez masowych Dz. U. 2009 nr 62 poz. 504.

Wądołowska, A. (2012). Zakaz wstępu na imprezę sportową jako jeden ze środków zwalczania przejawów chuligaństwa. In: W. Pływaczewski, B. Wiśniewski (eds.), Przestępczość stadionowa. Diagnoza i przeciwdziałanie zjawisku. Szczytno: Wydawnictwo Wyższej Szkoły Policji.

Wąsowicz, J. (2012). Biało-Zielona Solidarność. Gdańsk: Finna.

Wąsowicz, J. (2015). Moja Polska kibolska. Piła: Zakład Poligraficzny Henryk Górowski.

Wyrok Trybunału Konstytucyjnego z dnia 20 maja 2014 r., sygn. akt K 17/13.

Cite this article aS:. Brzana, T., Nowak, L., Nowak, M.A. (2016). The Fan Lifestyle on the Example of Soccer Fans. Central European Journal of Sport Sciences and Medicine, 15 (3), 71-84. DOI: 10.18276/cej.2016.3-08. 